\title{
Arch bridge design in eighteenth-century France: The rule of Perronet
}

\author{
Santiago Huerta \\ Universidad Politécnica de Madrid, Madrid, Spain
}

\begin{abstract}
Traditional design of masonry structures up to the twentieth century used empirical proportional design rules, independent of the scale. For buildings they were essentially correct: stability depends on the geometry, but not on the size, of the structure. Bridges support the pass of heavy traffic loads and the problem is non-proportional: for a given load smaller bridges are "weaker", more sensitive to action of the passing load. However until the eighteenth century the known rules were proportional. H. Gautier (1717) proposed first a non-proportional rule, but it was too conservative. J.R. Perronet (1748) produced a non-proportional rule for arch bridge-design both simple and reliable and justified it by the comparison with more than 200 existing bridges. Perronet's rule was in use for more than 100 years. In the present paper the use of Perronet rule and the development of arch bridge design during the eighteenth century will be studied, with a final discussion on the validity of the rules.
\end{abstract}

Keywords: 18 th century, Europe, Arch Bridge, Rules of Structural Design, Masonry

\section{INTRODUCTION}

Arch bridge design before the development of scientific structural analysis was based in empirical rules of design. The builders have acquired through their own experience and the study of existing buildings a deep understanding of the structural behaviour of arches. They codified this knowledge in the form of structural rules, which defined the form and size of the main elements involved. The first thing is to decide the profile of the arch. For a chosen profile, there are three main structural parameters: the thickness of the arch, and the depth of the piers (between the arches) and abutments (at both ends of the bridge). These parameters were usually "proportional" to the span of the corresponding arch. For example, in Roman arch bridges the relation thickness of the arch to span is most times between $1 / 10$ and $1 / 12$, though there are some exceptions. In the present paper we will concentrate in the problem of assigning a certain thickness to the arch of the bridge.

The first documentary evidence of the existence of structural rules for bridge design occurs in the late middle Ages. The oldest that I know is contained in a Manuscript dated in 1401, concerning the Stone Bridge of Zaragoza (Spain). In the first part the design of the piers of the different arcades of the bridge is discussed, to adjust the dimensions to the total length of the bridge. The master builders don't give the rule but it is evident that they are designing the bridge so that the piers are $1 / 3$ of the span (Huerta 2004, 178).
This rule of one third of the span appears again in Alberti's De re aedificatoria, The Art of Building, published in 1485 , but written thirty years before. The book covers all the aspects of design and construction in architecture, including bridge design. In Book Eight he gives the previous rule: "Let the piers be even in number and size, and have the width of one third that of their span" (Alberti 1992, 262). He gives also a rule for the thickness of the arches: "In a large bridge they should take up no more than one fifteenth of the total opening".

Alberti treats in more detail bridge design in Book Four, where he gives a set of rules which control the geometry of bridge (Alberti 1992, 111-2). For the piers: "The thickness of the pier should be a quarter of the height of the bridge". The thickness of the arches which limit the vault on both faces should be no less than 1/10 of the span: "... whatever the arch used to face the vaults, it should be composed of large blocks of extremely hard stone... The blocks used in the arch should be no thinner than a tenth of the chord". Eventually, Alberti gives another rule for the thickness of the piers which should be between $1 / 4$ and $1 / 6$ of the span: "The chords themselves should be no more than six and no less than four times the width of the piers". Alberti gives also rules for the foundations, their depth and width. The rules are so precise that a drawing of the bridge could be made (Straub 1952) (Fig. 1).

There is an apparent contradiction between the rule of 1/15 (Chap. 8) and 1/10 (Chap. 4). Most 
probably, the first applies to the vault thickness and the second only to the arches on the face of the bridge.

The rules may seem too crude in comparison to the extremely complex process of arch bridge design and construction. They constitute an orientation for the design; only a true bridge master builder could use the rules, and, eventually, deviate from them. Indeed, Alberti's section on bridges occupies one fourth of Book Six on Public Works

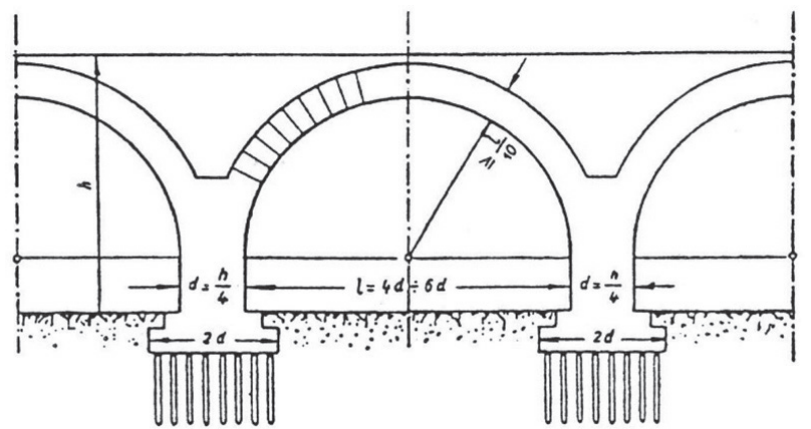

Figure 1. Alberti's rules for arch bridge design (Straub 1952).

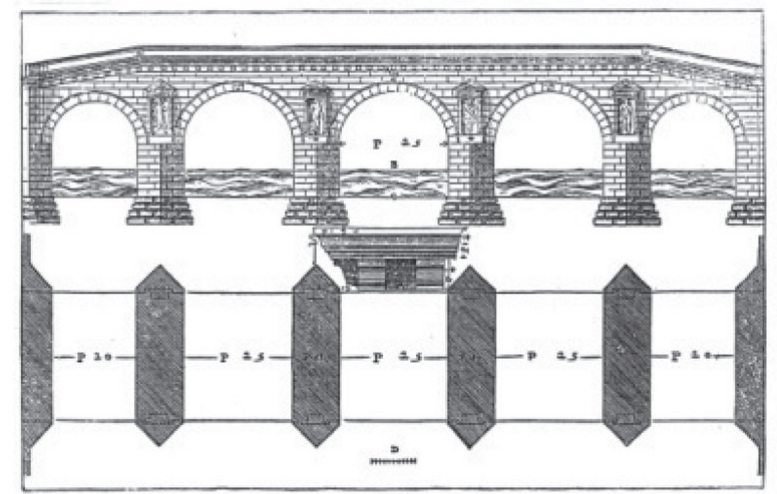

(a)

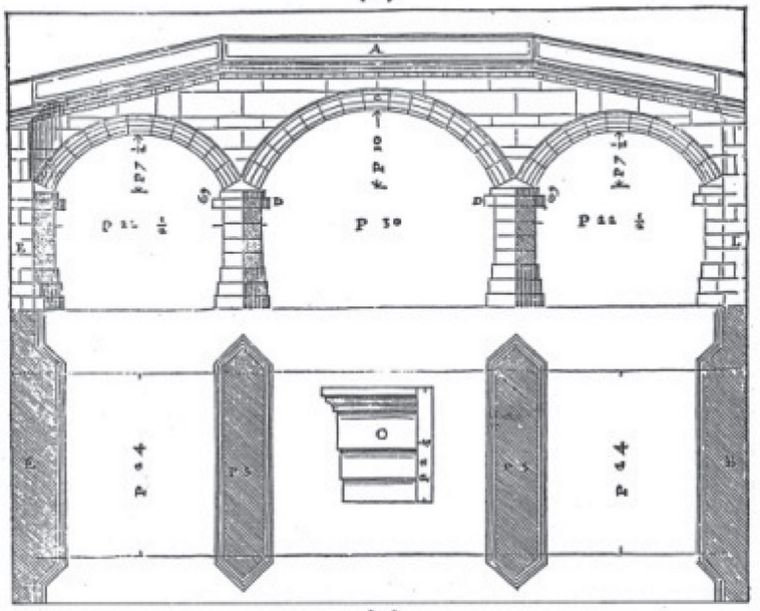

(c) and every aspect of bridge design is discussed: from its location, the way to build the foundations, the materials employed, etc., all this intertwined with historical events (the building of Julius Caesar bridge over the Danube, or the bridge built by King Menes at Memphis, diverting the Nile).

Some treatises don't give rules but they give examples. In the same way that a set of rules produces a safe geometry (Straub's drawing of Fig. 1), a surviving example of a bridge, or the elevation of a new design, contains safe proportions. Palladio (1570), for example, does not give general rules but give the proportions between arch and pier thickness to span in the four bridges he describes, (Fig. 2), Table 1.

Table 1. Bridge proportions in Palladio (cf. Fig. 2).

\begin{tabular}{ll}
\hline Bridge & Arch thickness/span \\
\hline (a) Roman bridge (Rimini) & $1 / 10$ \\
(b) Medieval ridge (Rerone) & $1 / 12$ \\
(c) Palladio's bridge (Vicenza) & $1 / 12$ \\
(d) Palladio's design & $1 / 17$ \\
\hline
\end{tabular}

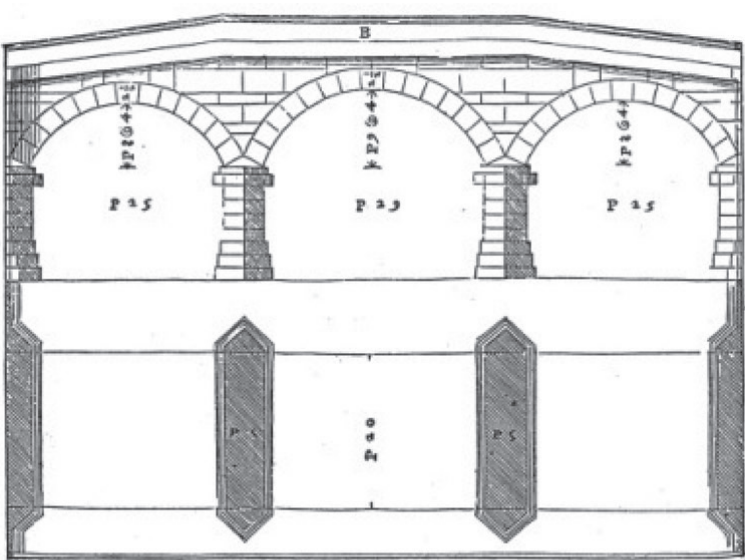

(b)

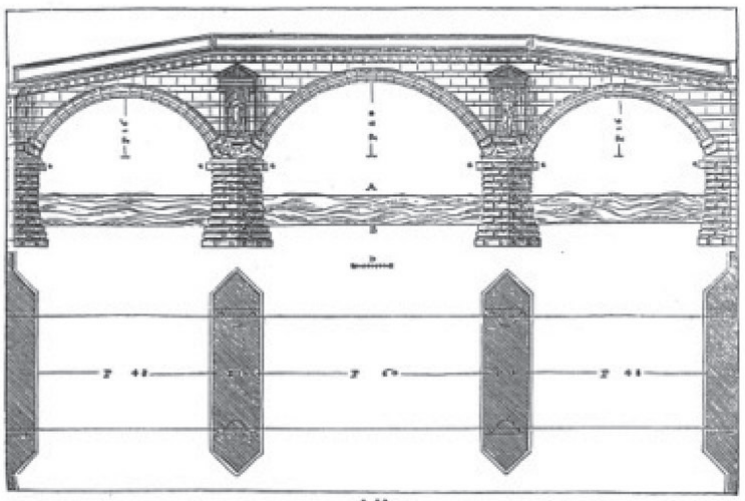

(d)

Figure 2. Bridges described by Palladio (1570). (a) Roman bridge of Rimini; (b) Medieval bridge over the Rerone; (c) Palladio's bridge in Vicenza; (d) design for a new bridge. 
It is evident that Palladio uses the same kind of design proportions as Alberti. The rest of architectural treatises treating on bridges until the eighteenth century usually cite Alberti's rule.

The rules were, of course, conservative. There are a number of Roman and medieval bridges with slender proportions. The main arch of the Roman bridge of Narni (21 m), as surveyed by Choisy (1873), presents a relationship thickness/ span of 1/17. The Roman Alcántara bridge in Toledo (28.8 m) 1/16 (Fernández Casado 1980). The late medieval bridge of Vielle Brioude, built in 1454 with $54.6 \mathrm{~m}$ span (reported by Perronet, see below), $1 / 28$, and the Rialto bridge in Venice (28.8 m), 1588-91, 1/37 (Rondelet 1837). The biggest stone arch built before the 20th was the bridge over the Adda in Trezzo built 1360-70, with a span of $72 \mathrm{~m}$, and presents a relationship of $1 / 35$ (Séjourné 1913).

\section{GAUTIER 1716, 1717}

The French engineer H. Gautier (1660-1737) published in 1716 a Traité des ponts, the first treatise on bridges. He begins his book complaining that in the architectural treatises bridges are treated superficially, not giving rules for design: "Les Auteurs qui onttraité de l'Architecture, n'ont point donné de regles pour construire des Ponts". Gautier wanted to write a comprehensive handbook compiling all that had been published before and adding all what he had learned from his experience of many years. The treatise supposed an enormous step in creating a discipline of bridge building.

Gautier expresses his conviction that arch safety is a matter of geometry and that all the elements should maintain a certain proportion for different sizes: "Plus les Arches sont grandes, quand on projette un Pont, plus les piles, les culées, et les voussoirs doivent augmenter, et avoir de portée à proportion" (Gautier 1716, 108). There is no sure rule to establish this proportion and one must recur to the existing works: "Nous n'avons point de regles seure pour déterminer la grandeur des voussoirsdans les Arches. Cen'est que sur les ouvrages déja faits, et sur les Antiques que l'on peut prendre des modeles, et faire une regle de proportion...".

For semicircular arches Gautier finds an excellent model in the Pont du Gard (Fig. 3). There the thickness of the arches is 4 feet for a span of 60 feet and the rule is, then, to take $1 / 15$ of the span (the same rule as Alberti, though Gautier doesn't mention him in the Traité).

However, Gautier remarks that the rule is only valid for arches with a span greater than 30 feet. As an example, he considers an arch of 1 toise (6 feet); after the rule the corresponding thickness

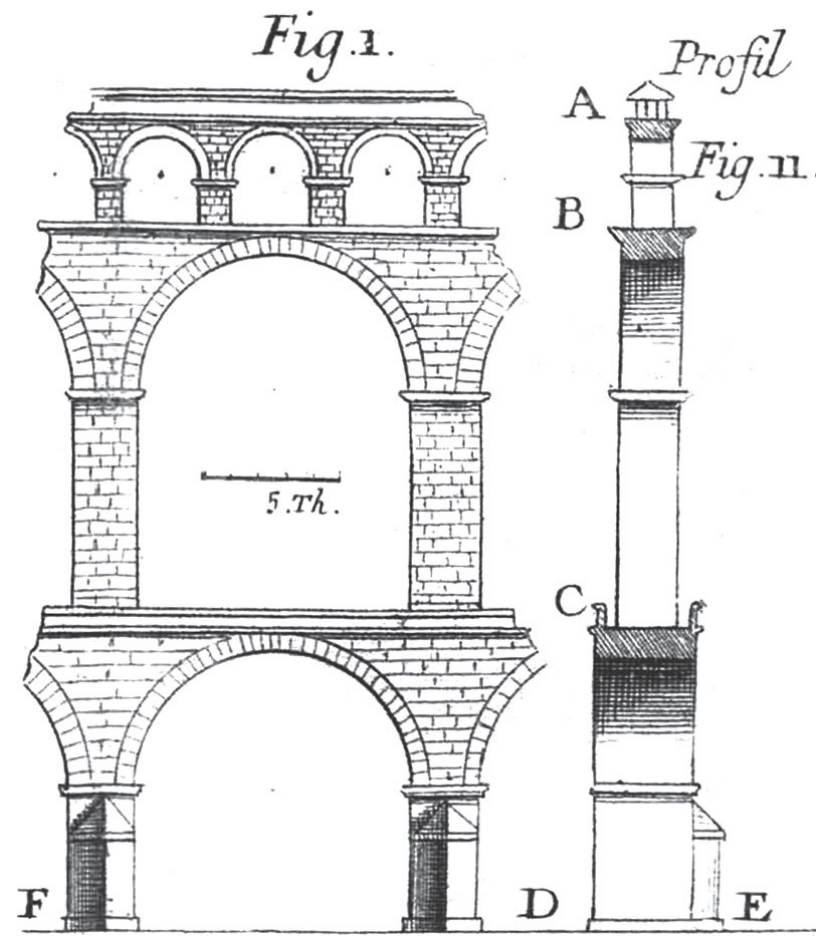

Figure 3. Pont du Gard (Gautier 1716).

will be less than 6 inches, which he considers very little compared with the correct thickness which, he says, is of 1.5 feet. Gautier explains that the origin of this discrepancy is that the effect of a certain load on the bridge diminishes as its size grows: "Il est certain qu'un grand Pont qui porte une grande voiture, est bien moins chargé qu'un Ponceau qui porte la meme voiture" (Gautier 1716, 109). This is the first time that the non-proportional character of arch bridge designis mentioned explicitly. The next year, in 1717, Gautier published a Dissertation sur l'epaisseur des culées des Ponts, sur la Largeur des piles, sur la Portée des voussoirs... It is not a treatise, but an investigation on the design of arches and their abutment piers. Gautier attempts to tackle the main problems of bridge design using the principles of mechanics, namely: 1) The thickness of the abutments; 2) Dimensions of piers; 3) Thickness of the arch; 4) Shape of arches; 5) Dimensions of retaining walls (Heyman 1982, 60). It is the third problem which is of interest here. Gautier dedicates a short chapter (the Fourth) to ascertain the thickness to be given to the arch ring at the crown, "Quelle doit estre la portée des Voussoir depuis leur intradoses à leur extradoses... à l'endroit de la Clef" (Gautier 1717, 22-31). Now he cites the rule of Alberti (span/15) and also discusses Palladio's stone bridges giving their respective proportions. Hequotes also that, after Serlio, the proportion of the Roman bridge of the Palatin in Rome is $1 / 12$. Without any further discussion or comment Gautier gives a "Table de proportion de 


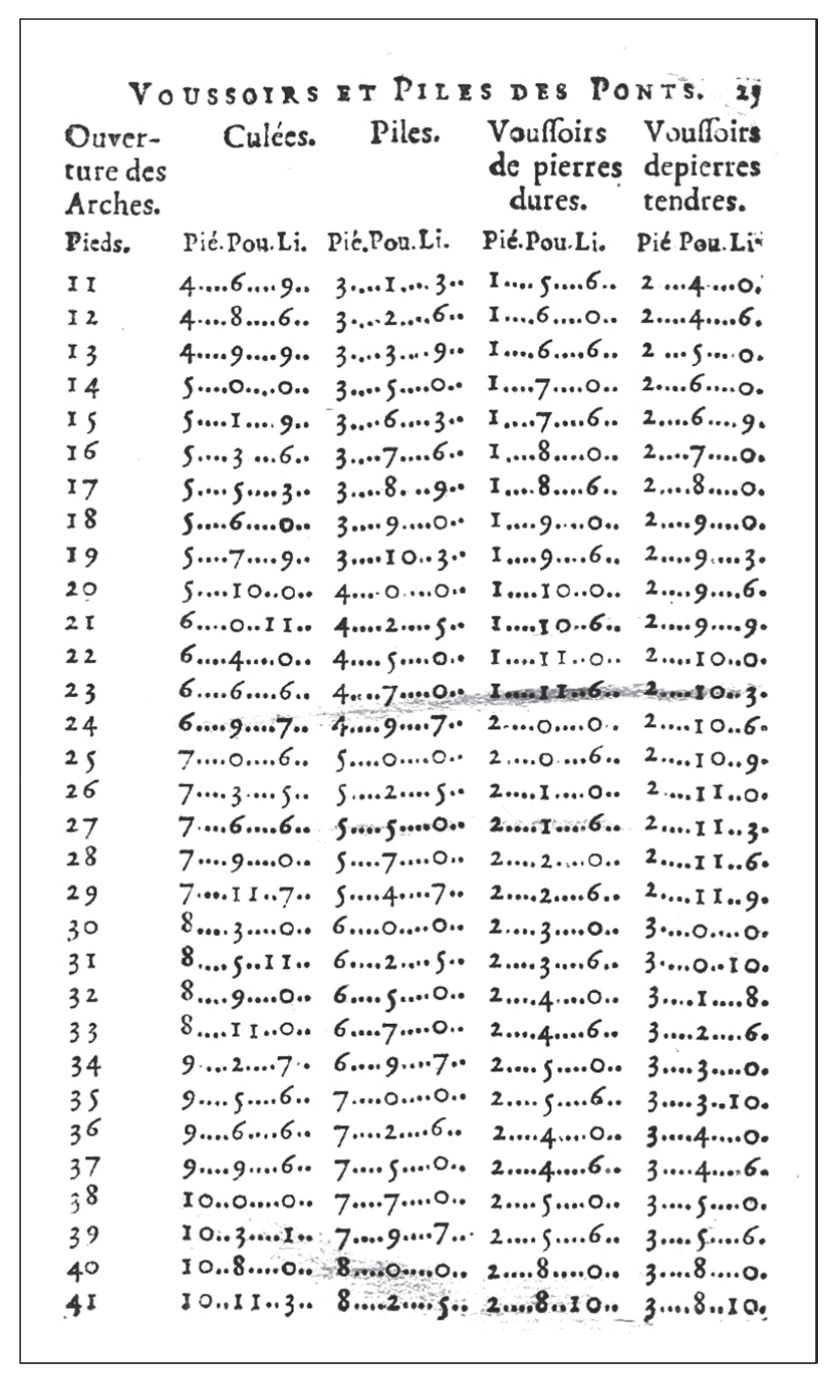

Figure 4. Page of Gautier's table to size the abutments, piers and arches (Gautier 1717, 24-28).

toutes les parties principales des Ponts" (Gautier 1717, 24-28). The Table is for semicircular arches between 1 feet and 120 feet span (Fig. 4). He says that the Table resolves the problem of bridge design and that he has obtained the proportions from "Authors" and "Old works" as the problem cannot be solved by the "justes Régles de Geometrie".

The Table give the dimensions of the abutments and piles, and the thickness of the voussoir at the keystone. This last dimension is given both for hard stones (pierres dures) and soft stones (pierres tendres). By studying the Table it is possible to deduce the rules from which it is based (which are not explicitly stated). Gautier distinguished between arches of more and less than 40 feet, and between "hard" and "soft" stones. The basic rule is that for hard stones; the thickness for soft stones is obtained by adding one foot (a close inspection reveals minor deviations from the rule).

For arches equal or greater to 40 feet, Gautier applies Alberti's rule of 1/15. For smaller arches
Table 2. Thickness at keystone (feet), Gautier Table (Fig. 4).

\begin{tabular}{lll}
\hline \multirow{2}{*}{ Span $s$} & \multicolumn{2}{l}{ Arch thickness at keystone (feet) } \\
\cline { 2 - 3 } & $s \leq 40$ feet & $s \geq 40$ feet \\
\hline Hard stones & $1+s / 24$ & $s / 15$ \\
Soft stones & $2+s / 24$ & $1+s / 15$ \\
\hline
\end{tabular}

the thickness is obtained adding 1 foot to $1 / 24$ of the span. The number " 24 " is convenient to work on feet, inches and lines. It gives, also, a "smooth" transition: for 40 feet, the application of both rules gives the same thickness $(1+(40 / 24)=40 / 15=2$ feet 8 inches, cf. Fig. 4).

In the second edition of the Traité des ponts (1728) the Dissertation was incorporated at the end, as well as series of documents related to the construction of several bridges. The Traité had two more editions in 1755 and 1765, and was widely cited. Bélidor incurporated the table in La science des ingénieurs (1729). It was cited frequently in European architecture and engineering manuals of the eighteenth century.

\section{PERRONET 1748}

Jean Rodolphe Perronet (1708-94) was one of the most important and influential engineers of the eighteenth century. He began his career working for one of the principal architects of Paris and throughout his life maintained an interest in architecture. In 1747 he was appointed director of the newly founded École des Ponts etChaussées, a position he held until his death. In 1763 he was appointed Chief Engineer of Ponts et Chaussées and in 1765 a member of the Académie des Sciences. He supervised the most important French public works of the second half of the nineteenth century. He himself built thirteen bridges and designed another eight. His works caused admiration for his audacity and lightness: the bridges of Neuilly (1774), SaintMaxence (1772-86) and de la Concorde (1787-91) are perhaps the most representative.

Perronet presented his theoretical work in the form of a few memoirs, some published and other unpublished, but which exerted a powerful influence on the evolution of the project of bridges in the second half of the eighteenth century and the first half of the XIX. In what follows we will concentrate on arch design.

\subsection{The unpublished Memoir of 1748}

In 1748, just one year after his appointment as Director of the École des Ponts et Chaussées, he wrote a memoir titled "Mémoire sur l'epaisseur que doivent avoir les voussoirs à la clef, dans les 
differentes voutes des Ponts" (Memoir on the thickness of the voussoirs in the keystone, in the different vaults of the bridges). The manuscript is kept in the Library of the Ecole des Ponts et Chaussées (Perronet 1748). In it Perronet proposed a rule for arch bridge design which was in use for almost 100 years and continued to be cited in masonry bridge handbooks until the end of the nineteenth century. It has an extraordinary interest, because Perronet discusses in detail the justification of the rule. The thickness should be obtained from the span, following the tradition of the old rules, and the problem is to find a general rule that relates these parameters to the scale and shape of the contemporary bridges. Perronet observes that if the dimensions of the old and modern bridges are studied, a great disparity of proportions is found between the thickness of arch ring and the span, even when they are built with the same stone.

Of course, he says, the smaller the thickness, the better the proportion will be because it leads to lower loads on the piles and abutments, which can be made more slender and thus facilitate the passage of water (Perronet 1748, 301).

The method followed to find the rule consists in examining the oldest and most solid arches where the thickness of the arch ring is smaller and extracting from them "a proportion that will be all the more certain as it is based on [the examination] of many arches". There is no safer method, says Perronet, because "in the matter of construction, speculation alone can not prevail over experience."

Perronet compiled a Table (Fig. 5), with the dimensions of more than two hundred arch bridges, old and contemporary, semicircular (Arches en plein cintre) or oval surbased to one third (Arches surbaissées au tiers), which he considers good examples in terms of the required conditions of solidity and economy. The table has a systematic structure and is designed to occupy two consecutive pages; its structure is as follows. On the left page, odd, in the first column, the examples of semicircular arches are described; the location and the main dimensions, span and thickness at the keystone are given.

The second column indicates the span in toises, feet and inches. The rows go at 2-foot intervals. The vertex of the parenthesis indicates, approximately, the corresponding place by the span of the bridge. The third column gives the thickness at the keystone given by the aforementioned formula. The next two columns, corresponding to the last

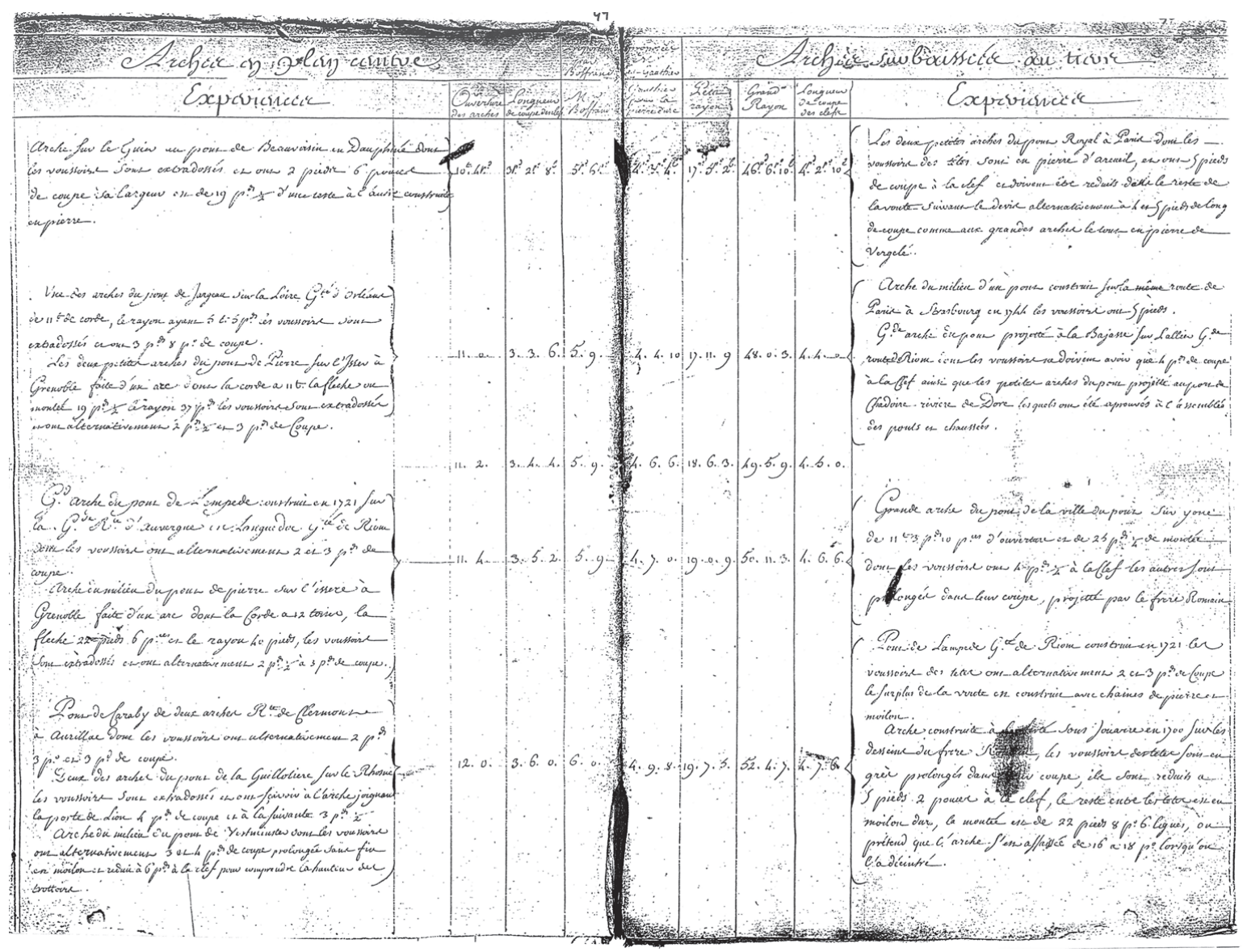

Figure 5. Table for arch bridge design (Perronet 1748). 
column of the left page and the first column of the right page, give the keystone thickness according to Boffrand and Gautier tables. Then come, for the same span, the two radii of curvature of the surbased arch (after Pitot's construction; see below). The penultimate column is the result of applying the formula with the large radius, and finally, the last column on the right collects the description of existing surbased arches for the corresponding span; again the vertex of the parenthesis, indicates approximately the situation of the "experience" and a description of the bridge follows.

\subsection{Semicircular arches}

For semicircular arches he arrives to the following rule: "[the thickness] will take a twenty-fourth of its span, adding one foot in favour of the smaller arcs, which must support the passage of the same loads as the large ones, and that it is necessary so that the progression do not start at zero. If, in addition, a line is removed from the thickness for each foot of light, this will give a proportion for the arch which will approximate to the arches selected as an example." Algebraically, the thickness $t$ (in feet) is a linear function of the span $s$ :

$t=s / 24+1-s / 144$

This expression could be reduced to: $t=1+s / 28.8$. Perronet's form will ease the calculations in feet and inches. The rule almost halved the thickness obtained by the Alberti-Gautier's rule for bridges. In fact, Perronet's rule is an extension of Gautier's rule for small arches with hard stones (Table 1). The third term reduces a little the thickness (one foot each 12 feet). It is a way to adjust the rule to some great bridge.

For example, the great arch of the medieval bridge of Vielle Brioude, at the end of his Table, with a span of 28 toises or 168 feet $(54.6 \mathrm{~m})$ and with a thickness at the keystone of 7 feet, fits almost exactly with the rule: 6 feet 10 inches.

\subsection{Surbased oval arches}

At the time when Perronet wrote this memoir oval surbased arch bridges were popular as they made easier the access for the roads. Usually they were three-centred ovals with a surbasement of $1 / 3$. This degree of surbasement was a standard until Perronet revolutionized arch bridge design in the 1770s. One of the first bridges of this type, and the most influential, was the Pont Royal, designed by J.H. Mansart and built in 1685 by J. V. Gabriel (Fig. 6). The greatest arch of this proportion was designed also by Mansart and built 1704-1710 with a span of 138 feet $(45 \mathrm{~m})$, but it collapsed

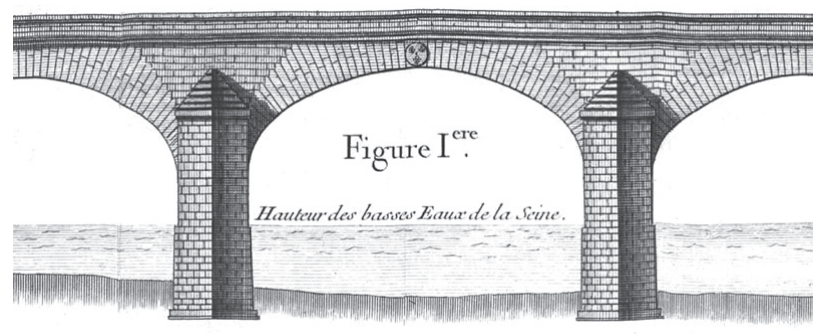

Figure 6. Central span of the Pont Royal, Paris (1685-87) designed by J.-H. Mansard (Bélidor 1753).

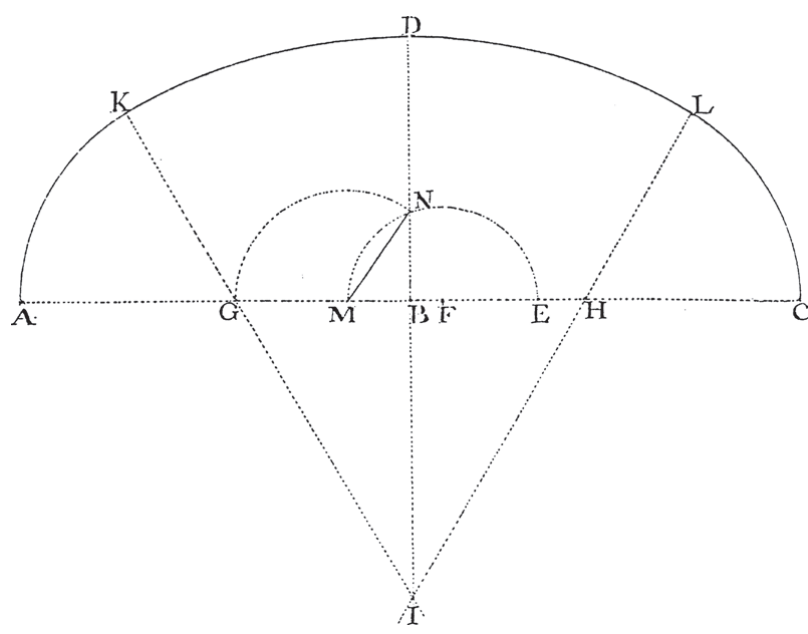

Figure 7. Surbased oval arch after Pitot (Perronet 1748).

shortly after for a failure of the foundations. Both are referred to in the Table. In fact many of the examples of surbased bridges in the Table were built in the first part of the eighteenth century.

There are several ways of constructing an oval arch of this proportion. In 1726 Pitot published a construction which became a standard for many years. This is the form considered by Perronet in his Table, (Fig. 6).

For surbased oval arches Perronet adapted the previous rule, substituting the span $s$ with $2 R$, twice the radius of curvature at the crown ( $t$ in feet):

$t=2 R / 24+1-s / 144$

The rule refers to oval arches after Pitot's construction, where $R=0.75 \mathrm{~s}$, nearly. Substituting above:

$t=s / 16+1-s / 144$

It appears that Perronet is taking as reference the Alberti-Gautier proportion. Indeed, the surbased bridges designed by Mansart, Gabriel, Hupeau, etc., in the first half of the eighteenth century presented a thickness of nearly $1 / 15$. 


\section{INFLUENCE OF THE RULE}

The rule of Perronet exerted a considerable influence, not only for the design of arch thickness. A few years later, 1751-52, working with Chézy, he produced another table to design the depth of the abutments after the theory of La Hire. The thickness of the arches was designed after the rule of 1748. This table remained unpublished until 1810 (Perronet and Chézy 1810). However it had a great influence. It was published, without citing the source, in the Cours d'architecture of Blondel and Patte (1771), perhaps the most influential of the second half of the eighteenth century. The tables were also incorporated in the Cours de construction by Sganzin, a very popular construction handbook, with five editions between 1806 and 1865 .

However, Perronet was well aware in the 1770 s that the rule was outdated. He cited it only once, in a footnote, in his memoir on the reduction of the thickness of the piles (Perronet 1777), remarking that it is adequate for "small arches". He proposes for the "great arches surbased to one third" $1 / 24$ of the span. E. Gauthey, writing ca. 1800, considered also the rule too conservative for big arches and proposed $1 / 24$, for arches between 16 and $32 \mathrm{~m}$, and for arches of more than $32 \mathrm{~m}$ span, " $1 / 24$ of the first $32 \mathrm{~m}$ plus $1 / 48$ of the rest" (that is, $3 / 2+s / 48$, in $\mathrm{m}$ ). If we apply the rule to the bridge of Vieille Brioude cited above $(54.6 \mathrm{~m})$ we obtain $1.8 \mathrm{~m}$ or 5 feet 7 inches (Perronet gives the actual thickness 5-7 feet; his rule, 6 feet 10 inches).

The "old" rule of 1748 was cited in most of the bridge treatises of the eighteenth century. However, bridges continue to grow in span and slenderness and the new empirical rules adapted to the new dimensions and proportions. All engineers agreed that the problem was too complex to admit a theoretical investigation. Quoting Rankine $(1862,425)$ : "To determine with precision the depth required for the keystone of an arch by direct deduction from the principles of stability and strength, would be an almost impracticable problem from its complexity". And he concluded: "The best course in practice is to assume a depth for the keystone according to an empirical rule, founded on dimensions of good existing examples of bridges".

Until 1850 the different rules followed the same linear approach of Perronet and Gauthey. For example, Dejard in (1845) proposed several rules $(t$ in $\mathrm{m})$. Among them:

- semicircular arches: $\quad t=0.30+s / 20$

- segmental arches $\left(60^{\circ}\right): \quad t=0.30+s / 40$

After 1850 different authors found useful to include the square root of one linear dimension of the arch, either the span $s$ or the radius $R$ of curvature at the keystone. A great quantity of rules was devised, always trying to adapt to long lists of built bridges. Some of the most popular are quoted below (Huerta 2004):

$$
\begin{array}{ll}
\text { Lesguillier (1855), m: } & t=0.1+0.2 \sqrt{s} \\
\text { Trautwine (1860), feet: } & t=0.36 \sqrt{R} \\
\text { Rankine (1862), feet: } & t=\sqrt{0.12 s} \\
\text { Dupuit (1870), m: } & t=0.2 \sqrt{s} \\
\text { Croizette-D. (1885), m: } & t=0.15+0.15 \sqrt{2 R}
\end{array}
$$

\section{DISCUSSION}

Most traditional design rules of masonry architecture are proportional (Heyman 1995, Huerta 2004). However, the design of masonry arch bridges is a non-proportional problem. For a certain surcharge $P($ a "knife-edge load" per $\mathrm{m})$ the following general expression could be written:

$P=\gamma L^{2} \Psi\left(\alpha_{1}, \alpha_{2}, \ldots\right)$

where $\gamma$ is the specific weight per $\mathrm{m}, L$ is a longitude describing the size of the arch and $\Psi$ is function of non-dimensional form factors $\alpha_{i}$. One of them is precisely $t / s$. The very complex form of the equation precludes extracting $t / s$ from the equation and the problem has no close solution.

Professor Heyman (1982) has written Eq. (1) with several form factors describing the geometry of a "general" bridge, to deduce a table for a quick checking of the stability of masonry bridges. The form factor $t / s$ is contained in it and simple inspection shows the transcendent character of the expression. Figure 8 shows the curves representing

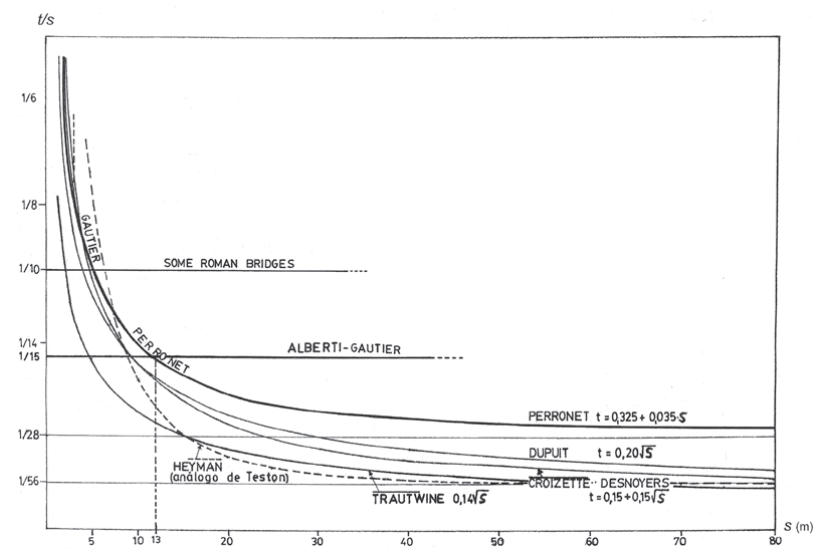

Figure 8. Rules for arch bridge design (Huerta 2004). 


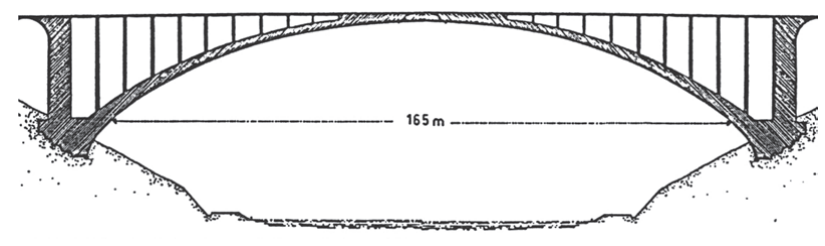

Figure 9. Viaduc du Bernand (Freyssinet 1913).

several of the cited rules, relating $t / s$ with the span $\sin \mathrm{m}$.

In general, it could be said that the rules were behind actual practice. First, an audacious engineer designed a new bridge breaking contemporary rules. Then, after some decades, a new rule incorporated the proportions of the said bridge. In Figure 8, a limit for thickness of ca. span/56 is evident. However, in 1913 Freyssinet designed the Viaduc du Bernand in unreinforced concrete with a clear span of $165 \mathrm{~m}$ and a proportion $\mathrm{t} / \mathrm{s}=1 / 78$. (The construction was interrupted by the 1 st World War.)

\section{REFERENCES}

Alberti, Leon Battista. 1992. On the Art of Building in Ten Books. London, Cambridge Mass.: The MIT Press.

Bélidor, Bernard Forest de. 1729. La science des ingénieurs. Paris: Claude Jombert (2nd ed. by L. M. H. Navier 1813).

Blondel, Jacques-François and Pierre Patte.1771-1777. Coursd'architecture. Paris Desaint.

Choisy, Auguste. 1873. L'art de bâtirchez les Romains. Paris: Ducher.

Freyssinet, E. 1913. "Viaduc du Bernard. Notice descriptive et justificative des dispositions adoptées", Revista de ObrasPúblicas e Minas (Portugal) 44: 123-145.
Gautier, Hubert. 1716. Traité des Ponts. Paris: André Cailleau. (2nd ed. 1728, 3rd ed. 1755, 4th ed. 1765).

Gautier, Hubert. 1717. Dissertation surl'epaisseur des culées des Ponts... Paris: André Cailleau.

Gauthey, Emiland-Marie. 1809. Traité de la construction des ponts. Paris: F. Didot, 1809-1813. (2nd ed. 1832, 3rd ed. 1843).

Heyman, Jacques. 1982. The Masonry Arch. Chichester: Ellis Horwood.

Heyman, Jacques. The Stone Skeleton. Cambridge: Cambridge University Press, 1995.

Huerta, Santiago. 2004. Arcos, bóvedas y cúpulas. Madrid: Instituto Juan de Herrera.

Palladio, Andrea. 1570. I Quattro libridell'Architettura. Venecia: Dominico de' Franceschi.

Perronet, Jean Rodolphe 1748. "Mémoire sur l'épaisseurquidoiventavoir les voûtes des pontsavectables et expériences" Ms. 2202, BibliotèqueÉcole des Ponts et Chaussées.

Perronet, Jean Rodolphe 1777. "Mémoire sur la réduction de l'épaisseur des piles..." Mém. Acad. Roy. Sciences, 853-64.

Perronet, Jean Rodolphe and AntoineChézy. 1810. "Formulegénéralepour determiner l'épaisseur des piles..." In Recueil de diversmémoires..., ed. Lesage2: 243-73. Paris: Didot.

Pitot, Henri. 1726. "Examen de la forcequ'ilfautdonnerauxcintres..."Mém. Acad. RoyaleSciences de Paris, 216-236.

Rankine, W. J. Macquorn. 1862. A Manual of Civil Engineering. London: Charles Griffin.

Rondelet, Antoine. 1837. Essaihistorique sur le Pont de Rialto. Paris: chezl'Auteur.

Séjourné, P. 1913-16. GrandesVoûtes. Bourges: ImprimerieVveTardy-Pigelet etFils.

Straub, Hans. 1952. A History of Civil Engineering. London: Leonard Hill.

Sganzin, Joseph Mathieu. 1809. Programmeourésumé des leçonsd'uncours de constructions...Paris: Goeury (1st. ed. $1806 ; 5$ th ed. 1865). 
PROCEEDINGS OF THE SIXTH INTERNATIONAL CONGRESS ON CONSTRUCTION HISTORY (6ICCH), BRUSSELS, BELGIUM, 9-13 JULY 2018

\section{Building Knowledge, Constructing Histories}

Editors

Ine Wouters \& Stephanie Van de Voorde

Vrije Universiteit Brussel, Belgium

Inge Bertels

Vrije Universiteit Brussel \& UAntwerpen, Belgium

Bernard Espion

Université Libre de Bruxelles, Belgium

Krista De Jonge

KU Leuven, Belgium

Denis Zastavni

Université Catholique de Louvain, Belgium

\section{VOLUME 2}


Cover illustration: Blaton Fund, AAM/CIVA, Brussels

CRC Press/Balkema is an imprint of the Taylor \& Francis Group, an informa business

(C) 2018 Taylor \& Francis Group, London, UK

Typeset by V Publishing Solutions Pvt Ltd., Chennai, India

All rights reserved. No part of this publication or the information contained herein may be reproduced, stored in a retrieval system, or transmitted in any form or by any means, electronic, mechanical, by photocopying, recording or otherwise, without written prior permission from the publisher.

Although all care is taken to ensure integrity and the quality of this publication and the information herein, no responsibility is assumed by the publishers nor the author for any damage to the property or persons as a result of operation or use of this publication and/or the information contained herein.

Published by: CRC Press/Balkema

Schipholweg 107C, 2316 XC Leiden, The Netherlands

e-mail: Pub.NL@taylorandfrancis.com

www.crcpress.com - www.taylorandfrancis.com

ISBN: 978-1-138-58414-3 (set of 2 volumes + USB)

ISBN: 978-1-138-33230-0 (Vol 1)

ISBN: $978-1-138-33235-5$ (Vol 2)

ISBN: 978-0-429-50620-8 (eBook set of 2 volumes)

ISBN: 978-0-429-44675-7 (eBook, Vol 1)

ISBN: 978-0-429-44671-9 (eBook, Vol 2) 